\title{
The Road to Transposing the Non-Financial Reporting EU Directive within the Romanian Context - The 2013-2020 Period
}

\author{
Professor Adriana TIRON-TUDOR, PhD, Teodora Viorica FĂRCAŞ, PhD, loana DRAGU, PhD, \\ Ecaterina Monica MOISE, PhD student \\ Babeş-Bolyai University, Cluj-Napoca, Romania
}

\begin{abstract}
Starting with 2016, the non-financial reporting became mandatory for certain types of entities in the European context due to the introduction of the Directive 2014/95/EU, and the Directive has been transposed in the Romanian context, a country without a CSR reporting tradition. This paper aims to discuss the main concerns at European and national level regarding the effectiveness of this form of regulation. To achieve this aim, we enrol in extensive research using the framework of neo-institutional normative theory and the qualitative methodology based on a literature review of academic debates and documentary analysis of the transposition process, highlighting the harmonization of the Romanian regulation to the EU Directive. Therefore, the contribution of this paper is to reveal the transposition's outcome in the context of the economic-, government- and society-related factors in Romania, taking into consideration the historical, cultural, economic and political local contexts.
\end{abstract}

Key terms: Directive 2014/95/EU, non-financial reporting, Romania, voluntary/mandatory disclosure, NFRD

\begin{abstract}
Acknowledgements: The results presented in this paper represents a part of the research conducted by the team in the frame of INTEREST-INTEgrated REporting for SMEs Transparency project, ERASMUS+ KA2 - Strategic Partnership 2019-1-HU01-KA202-060911
\end{abstract}

JEL Classification: M40

To cite this article: Adriana Tiron-Tudor, Teodora Viorica Fărcaş, loana Dragu, Ecaterina Monica Moise, The Road to Transposing the Non-Financial Reporting EU Directive within the Romanian Context - The 2013-2020 Period, CECCAR Business Review, No 6/2020, pp. 63-72, DOI: http://dx.doi.org/10.37945/cbr.2020.06.08

\section{Introduction}

Currently, there are many standards, guidelines, and frameworks, created by global reporting bodies, that companies use as a reference for NFI reporting. From the stakeholders' point of view, this variety of NFI reporting practised by companies induced confusion due to the inability to meaningfully compare companies on environmental, social, and governance (ESG) topics (Bonsón and Bednárová, 2015). If companies are disclosing different types of data using different measurements, it makes it almost impossible to compare or to identify trends. Conversely, if companies are using a structured ESG reporting, both stakeholders and companies have benefits: stakeholders will have a clearer idea about the companies' ESG issues, while companies will gain in accountability and legitimacy. Greater transparency and consistent, comparable ESG information might contribute to restoring trust in businesses, which is timely in the current situation. 
At European level, the EU Commission showed its sensitivity towards the ESG topic, became more and more interested in ESG issues, and continuously tried to debate and promote better ways to manage the ESG matters at macro- and micro-level. Since the 2011 EU Commission Communication "Single Market Act", companies are requested to provide more and transparent information on social and environmental matters, also known as sustainability reporting. Finally, Directive 2014/95/EU (NFRD), which became effective for annual reports in 2018, regulated mandatory non-financial reporting for large undertakings and groups in Europe (Dumay et al., 2019), but left at the transposition into national regulation and implementation at the Member States' discretion, with considerable flexibility, recommending various frameworks as guidance.

In this context, the paper aims to analyse the transposition of the NFRD in Romanian regulation by taking into consideration the country's particularities. Moreover, the debate will reflect the main concerns at European and national level regarding the effectiveness of this form of regulation. The framework of neo-institutional normative theory provides a suitable frame to achieve the aim of this research. A qualitative methodology based on a literature review of the academic debates, together with a documentary analysis on how prepared Romanian entities are to provide non-financial information, present the transposition process highlighting the harmonization of the Romanian regulation to the EU Directive.

Therefore, this paper contributes to the development of corporate reporting literature, revealing the transposition outcome in the context of the economic-, government- and society-related factors in Romania, taking into consideration the historical, cultural, economic and political local contexts.

\section{NFRD academic debates}

The NFRD topic was debated before, during and after its issuance by the academia, from different perspectives, as follows: the NFRD content and the influencing factors of non-financial reporting, benefits, weakness; how the companies reported NFI before and after the NFRD was issued; and finally, transposition into national legislation.

The NFRD's content and the influencing factors of non-financial reporting are widely debated (Kinderman, 2015; Krištofík et al., 2016; Monciardini et al., 2017; Aureli et al., 2019; Dumay et al., 2019; Grewal et al., 2018; La Torre et al., 2018; Manes-Rossi et al., 2018).

Corporate reporting literature mentions the following benefits resulting from the NFRD being issued:

$\checkmark$ Standardization of NFR is seen as a solution for the problem of over-reporting inadequate information, which might increase the companies' transparency and quality by ensuring comparability at international level and between different sectors (Krištofík et al., 2016; Kamiński, 2018; La Torre et al., 2018; Caputo et al., 2019).

$\checkmark$ Considerable flexibility in transposition and application (Monciardini et al., 2017; Aureli et al., 2019; Camilleri, 2018).

$\checkmark$ NFRD has an essential role in the convergence process of NFI related to social responsibility, and sustainability reporting (Klaus et al., 2016).

$\checkmark$ NFI reporting harmonization at European level (La Torre et al., 2018; Carini et al., 2018).

$\checkmark$ EU corporate reporting harmonization may progress due to NFRD (Kamiński, 2018; Camilleri, 2018).

Still, the same literature reveals that NFRD also has weaknesses, namely:

$\checkmark$ A too traditional, backward and old-fashioned policy (La Torre et al., 2018), not up-to-date with the current context of the digital era so as to propose better ways for communicating information.

$\checkmark$ The lack of standardization for the external verification of NFR by an independent assurance services provider, which diminishes accountability and NFI comparability (La Torre et al., 2018; Dumitru et al., 2017; Saenger, 2017; Aureli et al., 2019; Grewal et al., 2018).

$\checkmark$ Additional costs for companies (La Torre et al., 2018; Grewal et al., 2018). 
$\checkmark$ The NFRD's flexibility, because it allows companies a high autonomy in choosing the method and the content of the information disclosed, creating ambiguity in interpretation, and compromising the comparability (Aureli et al., 2019; Kinderman, 2015).

Many researchers show interest in the analyses of companies' NFI reporting, either focusing on a single state, or conducting comparative studies between states. These studies show the different level of disclosure between regions and industries, in a pre- and post-implementation perspective or focusing specifically on the post-implementation period in countries with a tradition in reporting NFI or non-traditional NFI reporters (Peršić et al., 2017; Dyduch and Krasodomska, 2017; Matuszak and Rózańska, 2017; Venturelli et al., 2017; Aureli et al., 2019; Carini et al., 2018; Manes-Rossi et al., 2018; Caputo et al., 2019; Fărcaș, 2020). The NFRD's impact is higher in countries where NFI reporting is less developed (having no tradition in NFI reporting), as is the case of Romania, than in countries where companies are already accustomed to report NFI on a voluntary or mandatory basis (Dumitru et al., 2017; Tiron-Tudor et al., 2019).

The national transposition of the NFRD constitutes a topic of interest both for the academia and practitioners/regulators at European and national level. In this sense, the study commissioned by the EU (GRI, CSR Europe and Accountancy Europe, 2017) offers an overview of the NFRD's implementation by Member States transposing it into the national regulation. The study reveals the vast diversity in the NFRD's application, illustrated are follows. The NFRD requirements concerning the definition of large companies are the same in the national regulations of 19 out of the 30 states included in the study, and the others adapted it. On the other hand, the public interest entity definition is the same as in the NFRD only in 6 out of 30 states, while 14 preferred to adapt it. Concerning the reporting framework and topics to be reported, contents were fully adopted from the NFRD in most countries (22/30). The placement of NFI disclosure was adapted to the states' context and not adopted as in the NFRD in the majority of countries (23/30). Assurance requirements for non-financial disclosures were adopted as in the NFRD in most countries (20/30). Non-compliance penalties were adapted to context in most European countries. Conversely, diversity reporting was adopted fully in most countries (19/30). Only in the case of non-compliance penalties and safe harbour principle, less than five states omitted these from their national regulations, while the others adapted the non-compliance penalties to the national context and adopted the safe harbour principle requirements as in the NFRD.

These elements, and others related to the national context, were explored by researchers with a specific focus on the context of particular Member States, such as Italy (Venturelli et al., 2017; Caputo et al., 2019), France (Malecki, 2018), Germany (Saenger, 2017), Poland (Matuszak and Rózańska, 2017), Romania (Fărcaș, 2020), or in a comparative manner between two or three states, such as Poland and Romania (Dumitru et al., 2017), and the UK, France and Italy (Aureli et al., 2019).

\section{O Methodology}

The institutional theory provides a complementary perspective to the stakeholder theory and the legitimacy theory to investigate the transposition of the NFI reporting regulation in the national context. The institutional theory focuses on the analysis of external factors and their impact on the entity. The article explores the impact of the EU's institutional pressure on the choice made by Member States (Börzel, 2005) for transposing the Directive concerning NFI reporting. The EU Directive is a form of coercive mechanism that should lead to isomorphism. However, compliance with EU regulations may vary because of the role played by different domestic institutions that also exercise pressures (Börzel and Risse, 2003). Institutional processes can be top-down, which means, in the case of Romania, a two-stage process - first, that the Romanian government may adapt to the top-down pressure coming from supranational actors such as the EU, and in the second stage, the entities may adapt to the top-down pressure coming from the government. 
Previous accounting research demonstrates that national financial reporting regulations are heavily influenced by local factors (e.g., legal system, financing system), and that national differences continue to exist even after the mandatory use of a regulation, e.g., IFRS (International Financial Reporting Standards) for listed companies (Nobes, 2006). Similarly, the countries' institutional factors remain relevant under IFRS and give rise to international differences in the accounting policy choice.

The research methodology focuses on formal implementation and involves two main stages, namely: the positivist approach and the critical approach. First, we develop a narrative discourse analysis, reviewing the most relevant studies in the non-financial reporting literature. Secondly, we analyse the process of NFRD adoption in Romania taking into consideration the institutional factors that might influence the NFRD's transposition. In the second stage of our research we undertake a critical approach of document analysis, by investigating the Romanian regulations related to transposing both mandatory and optional NFRD requirements at national level. The outcome is analysed in light of the economic-, government- and society-related factors in Romania (Jamali and Neville, 2011) that define the historical, cultural, economic and political local context.

\section{$\ni$ Results}

\section{- The transposition of the 2013/34/EU Directive into Romanian regulation (2014-2015)}

The introduction of the pioneering EU Directive on the disclosure of non-financial and diversity information (EU, 2014) regarding environmental, social, employee-related, diversity, human rights, anti-bribery and anticorruption matters marked a definitive step towards a greater transparency and accountability on social and environmental issues, to the benefit of all stakeholders (Global Reporting Initiative (GRI), 2017), for individual large companies.

In Romania, mandatory requirements related to non-financial information existed only for listed companies (CNVM, 2006), while for other companies, disclosures were made on a voluntary "as the case may be" basis. On a voluntary basis, Romanian subsidiaries of international groups make more NFI disclosures than other companies. In relation to sector and ownership, environmentally sensitive companies and state-owned companies present NFI reports. These companies are using NFR international frameworks, and the majority have Big 4 auditors (Dumitru et al., 2017). Regarding the quality of NFI reporting in Romania, there is a positive trend: companies seem to engage in environmental initiatives, moving in time from disclosing low quality, inconsistent information to more consistent information (Dumitru et al., 2017; Tiron-Tudor et al., 2019).

The partial transposition of the 2013/34/EU Directive into the Romanian legislation was done by the Minister of Public Finance through OMPF No. 1802/2014. However, in a deliberate minimalist manner, as described in the Directive, in the management report provided for in OMPF No. 1802/2014, Chapter 7, Art. 491, Director's report: "where appropriate, the report shall include non-financial key performance indicators relevant to the particular business, including information relating to environmental and employee matters". Moreover, Art. 492 excludes micro-entities and small entities, which are not required to disclose NFI.

OMPF No. 1802/2014 refers to the following non-listed companies: national companies/enterprises, government entities with autonomous administration ("regii autonome"), national research institutes, cooperative companies and other legal persons working as companies, branches or subsidiaries, but in Section 2.1 para. 8 defines PIEs as "national companies/enterprises, companies with full or majority state ownership and other state-owned entities with autonomous administration ("regii autonome")". For listed companies, OMPF No. 150/2015 defines PIEs as the entities included in Art. 1 of OMPF No. 1286/2012, so all listed entities are included in the PIE definition. Moreover, OMPF No. 150/2015 includes requirements concerning a corporate governance statement that will describe the entity's corporate governance issues. For the credit and insurance sector, their regulatory bodies issued similar regulations, presented in the table below. 
Concerning entities, the PIE definition transposition into Romanian regulation was done by different regulations related to the sectors in which they are operating.

PIE definition transposition into the Romanian regulations

\begin{tabular}{|l|l|}
\hline \multicolumn{1}{|c|}{ 2013/34/EU Directive, Art. 1: PIE definition } & \multicolumn{1}{c|}{ PIE transposition into Romanian regulation } \\
\hline Listed entities & OMPF No. 150/2015 \\
\hline Credit institutions & $\begin{array}{l}\text { NBR Orders No. 6/2015 and No. 7/2015 } \\
\text { ASF Pronouncements No. 14/2015 and No. 40/2015 }\end{array}$ \\
\hline Insurance undertakings & ASF Pronouncements No. 36/2015 and No. 41/2015 \\
\hline $\begin{array}{l}\text { Entities designated by Member States as public- } \\
\text { interest entities, for instance undertakings that } \\
\begin{array}{l}\text { are of significant public relevance because of the } \\
\text { nature of their business, their size or the number } \\
\text { of their employees }\end{array}\end{array}$ & $\begin{array}{l}\text { OMPF No. 1802/2014: not listed national } \\
\text { companies/enterprises, companies with full } \\
\text { or majority state ownership and other state-owned } \\
\text { entities with autonomous administration } \\
\text { ("regii autonome") }\end{array}$ \\
\hline
\end{tabular}

Source: Own compilation.

In a brief estimation, according to the CSR Report (2018) using 2015 publicly available data, 680 publicinterest companies with more than 500 employees were included under the 2013/34/EU Directive in Romania in its first year of application, meaning that in 2018 it was mandatory for these companies to publish non-financial information for the year ended on 31 December 2017. 23.32\% of these companies were owned by the state, while a low percentage of $6 \%$ were companies listed on the BVB (Popescu and Banța, 2019). The analysis of 246 of these companies based on their annual reports for 2017 prepared in 2018 reveals the type of NFI concerning social responsibility, the environment, and promotion of ethical and sustainable business, care for the employees, the environment, and the local community published by the Romanian companies (Popescu and Banța, 2019). Moreover, the reports include procedures to prevent conflicts of interest and incompatibilities, a full list of senior management, the development of codes of conduct and ethics, sponsorship and financial aid, compliance with all laws. The social aspects presented include social impact management, respect of human rights, training and promotion opportunities, employee health, safety and welfare, responsibility towards employees, the removal of any possible sources of dangers at work. Concerning the environment, reports expose an internal/external environmental assessment. Another disclosure refers to authorizations or certifications for the environment, water management, connection-discharge, environment, quality, the effectiveness of resource use, research and development, statements of assets and interests of management personnel.

\section{- NFI reporting in Romania in the NFRD period (2016-2020)}

\section{a) Non-financial statement content and reference}

Romania used a partial transposition approach for the NFRD requirements that entails significant changes in the legislation for listed and non-listed companies (OMPF No. 1938/2016, OMPF No. 2844/2016, OMPF No. 3456/2018), as presented below. For certain types of entities, such as financial and credit institutions, specific regulations were issued (NBR Order No. 7/2016 and ASF Pronouncement No. 1/2017). The National Bank of Romania (NBR), the Bucharest Stock Exchange (BVB), and the Financial Supervisory Authority (ASF) contributed equally to the mechanism for improving the legislative framework for transposing the EU directives in our country for their respective fields.

The significant contribution to the NFRD transposition brought by OMPF No. 1938/2016 that supplements OMPF No. 1802/2014 consists in introducing the concept of non-financial statements into the Romanian corporate 
reporting legislation for non-listed entities and dedicating to it a separate section entitled "Non-financial statement" (Art. 492), and Consolidated Non-Financial Statement (Art. 556), respectively, for groups of companies. In the same manner, for listed companies, OMFP no. 2844/2016 replaced OMPF No. 1286/2012 and introduced a separate chapter entitled "Non-financial information and information regarding diversity", which includes two sections - "Non-financial statement" (Art. 39-43), and "Consolidated non-financial statement" (Art. 44-48) for groups of companies, which became effective on 1 January 2017.

Both regulations (OMPF No. 1938/2016 and OMPF No. 2844/2016) transpose mandatory NFRD requirements concerning NFI reporting, at least on environmental, social and personnel issues, respect for human rights and combating corruption and bribery, including:

"a) a brief description of the entity's business model;

b) a description of the policies adopted by the entity concerning these matters, including the due diligence procedures applied;

c) the results of the respective policies;

d) the main risks related to these matters arising from the entity's operations, including, when relevant and proportionate, its business relationships, its products or services that could harm the respective areas, and the way in which the entity manages those risks;

e) non-financial key performance indicators relevant to the specific activity of the entity".

Moreover, if the entity does not implement policies regarding one or more of the mentioned matters, the non-financial statement provides a clear and reasoned explanation regarding this option, following the comply or explain principle.

Also, Romanian regulations specify which information and indicators should be provided in addition to the list of matters (from letters a) to e)) reported according to the NFR Directive, concerning environmental aspects, details regarding the current and future impact of the company's activities on the environment and, where appropriate, health and safety, use of renewable and non-renewable energy sources, emissions of greenhouse gases, use of water resources and air pollution. As far as social and personnel issues are concerned, information can refer to the actions taken to guarantee gender equality, the application of the International Labour Organization's conventions, working conditions, social dialogue, respecting the rights of workers to be informed and consulted, respect for trade union rights, health and safety at work, dialogue with local communities and/or actions taken to ensure the protection and development of these communities. Concerning human rights and the fight against corruption, the non-financial statement may include information concerning the prevention of human rights violations and/or the instruments set up to fight corruption. The non-financial statement also includes the impact of the company's activities and the goods and services that it produces on climate change, as well as its commitment to sustainable development, the fight against food waste and the fight against discrimination, and the promotion of diversity. Moreover, the regulation specifies that the required information is not limited.

The NFRD allows Member States to opt for a national, international or European reporting framework for non-financial information, but, at the same time, requires them to indicate the standards or frameworks that companies may adopt for preparing the non-financial statement. Both Romanian regulations mention that entities can use any national, EU or international framework as a reference to prepare non-financial information; the framework used will be mentioned by the reporting entity, thus providing total freedom to entities on this matter. However, this fact harms comparability at the national level for all industries, in general, and between industries, in particular.

\section{b) Scope of PIES}

The NFRD refers to "large undertakings which are public-interest entities exceeding, on their balance sheet dates, the criterion of an average number of 500 employees during the financial year". OMPF No. 2844/2016 
extended the PIE definition by adding to the listed companies 17 state-owned entities mentioned in OMPF No. 666/2015, and OMPF No. 3456/2018 extended the scope of the NFRD to all entities that, individually or at consolidated level, have an average of over 500 employees, whether they are of public interest or not, thus taking the option granted to the EU Member States to extend the scope of the EU Directive beginning with reports for the 2019 financial year. This also includes European companies with headquarters in Romania and subsidiaries of foreign companies officially registered on Romanian territory.

\section{c) The non-financial statement - part of the management's report or a separate report, and responsibilities}

Romania adopted the same approach as the NFRD concerning the possibility for Member States to allow the presentation of a separate report containing non-financial information instead of providing the non-financial statement within the management's report and the deadline to make the reports available to the public. Romanian regulation gives more freedom to entities regarding the possibility of disclosing the non-financial statement in the management's report or a separate report for the same financial year, whether or not that report is based on national, EU or international frameworks, which include the information required for the non-financial statement. The separate report must be published together with the directors' report, or made available to the public within a reasonable period not exceeding six months from the balance sheet date, on the entity's website, and be mentioned in the directors' report.

Regardless of whether the non-financial statement is included in the management's report or in a separate report published together with the management's report or made available to the public, the responsibilities and accountability for its preparation and publication in compliance with the national legislation rest with the members of the administrative, management and supervisory bodies of the legal entity. Moreover, non-compliance with this requirement concerning the non-financial statement's publication in one of the forms presented above, together with the annual financial statement, is considered a contravention and shall be sanctioned by a fine according to Art. 42 para. (1) of the Accounting Law.

\section{d) NFI audit/assurance}

Another essential section of the legislation refers to the third-party verification or audit of the non-financial information reported. The NFRD mentions that the Member States may require that the information in the non-financial statement included in the management's report or in the separate report is verified by an independent assurance services provider. The EU requires the statutory auditor or an audit firm to verify the existence of the non-financial statement inside the management's report or in a separate report and lets Member States decide whether to also require the verification of the document's content. In this case, Romania chose not to require assurance for the non-financial statement's content at national level. The statutory auditor or statutory audit firm shall verify whether the non-financial statement was provided in the management's report or a separate report.

In 2018, the OMPF No. 470/2018 introduced a new paragraph in OMPF No. 1802/2014 in order to mention the "Guidelines on non-financial reporting (methodology for reporting non-financial information)" issued by the European Commission in 2010 as the framework used by the regulation concerning the non-financial information that must be disclosed by Romanian companies.

\section{e) Assessment of non-financial information provided by the Romanian companies}

A first assessment on the disclosure levels of Romania's listed companies pre- and post-implementation of the NFRD and its determinant pre- and post-directive adoption decisions in Romania's case was done by Tiron-Tudor et al. (2019). The results emphasize that Romanian Energy (Oil and Gas and Utilities) listed companies 
are outlining in their reports environmental, social, and governance issues. The empirical research performed through a pre-/post-effect analysis of the level of non-financial disclosure, followed by an exploration of its determinants' analysis, demonstrate a slight increase in the level of disclosure after the effective date of the EU Directive. Moreover, Energy companies demonstrated a considerable increase in terms of disclosure, as well as a focus and awareness regarding ESG issues. Research findings lead to an increasing effort to comply with the EU Directive requirements, and the information proved useful for practitioners and policymakers. Also, Marinescu (2020) analyses how these companies publish non-financial information in the separate report, and for what reasons. The study reveals the companies' tendency to imitate best practices for drafting the reports. The reason for the separate publication of the NFI report is to attract investors and create an international image. Applying a multiple case study methodology on the same sample of 10 listed companies (most with Romanian capital) included in the BETPlus Index, Fărcaș (2020) concludes that the implementation of the Directive into the Romanian legislation represented a step forward for non-financial reporting, with the companies' response being positive, and in most cases having a considerably important place within the annual statements.

\section{Discussions and conclusions concerning the NFRD's transposition in the specific local context}

This paper investigates non-financial disclosures in Romania, after the European Directive's adoption, and how Romania faced EU institutional regulatory pressure for non-financial reporting.

Romania represents an interesting case due to its evolution, shifting from a centralized planned economy to a market economy, being developing country governed by the rule of law, with an emerging economy, but also being an EU member since 2007. The specific geographical location of Romania shapes and influences the national political and economic context. In particular, its European Union membership determines the general directions for development criteria, structural integration at continental level, and, in the specific case of the research, the corporate reporting trend including financial and non-financial reporting.

Concerning the NFRD's effectiveness, at least from the analysis of Romania's case, the application is problematic. First of all, the comparability of non-financial statements is questionable, as there is no recognized reporting framework at national level, especially in a rule-based context. Moreover, the NFRD's considerable flexibility results in different options in different states and, as a consequence, the comparability between states is debatable. Secondly, from an audit perspective, how auditing is being conducted can impact the relevance and reliability of the information provided to users. Based on these considerations, the NFRD's attempts to move toward harmonization of non-financial reporting across Europe, in order to achieve a similarly high level of transparency across companies in the EU Member States in disclosing the impacts and risks related to society and the environment, as demanded by public authorities, investors and civil society organizations, are compromised in this regulation and its implementation in the Member States.

The research findings are relevant to practice and policy. The paper's conclusions might support the importance of regulations to strengthen the extent and quality of NFR. This ex-ante evaluation of transposing reporting regulations into the national regulations and, at the same time, into practice is useful for understanding how changes occur in practice and how the Romanian government met the institutional demands and the pressure of EU regulations and elected how to best transpose the EU Directive in this case by also taking into consideration the national, local context.

Concerning the road of the NFRD transposition process, Romanian authorities have tried to minimize the transposition costs by using the flexibility granted to the Member States, as well as the companies' costs. Romanian regulations concerning non-financial statements comply with the EU Directive requirements in relation to the following items: reporting framework, disclosure format, safe harbour principle, and required diversity reporting; and adapted the definition of entities (PIE with more than 500 employees), report topics and content, auditor's involvement, and non-compliance penalties. 


\section{Bibliography}

1. Aureli, S., Magnaghi, E., Salvatori, F. (2019), The Role of Existing Regulation and Discretion in Harmonising Non-Financial Disclosure, Accounting in Europe, Vol. 16, No. 3, pp. 290-312.

2. Bonsón, E., Bednárová, M. (2015), CSR Reporting Practices of Eurozone Companies, Spanish Accounting Review, Vol. 18, No. 2, pp. 182-193.

3. Börzel, T.A. (2005), Europeanization: How the European Union Interacts with its Member States, in S. Bulmer, C. Lequesne (Eds.), The Member States of the European Union, Oxford University Press, Oxford, pp. 43-69.

4. Börzel, T.A., Risse, T. (2003), Conceptualizing the Domestic Impact of Europe, in C.M. Radaelli, K. Featherstone (Eds.), The Politics of Europeanization, Oxford University Press, Oxford, pp. 57-81.

5. Camilleri, M.A. (2018), Theoretical Insights on Integrated Reporting: The Inclusion of Non-Financial Capitals in Corporate Disclosures, Corporate Communications: An International Journal, July.

6. Caputo, F., Leopizzi, R., Pizzi, S., Milone, V. (2019), The Non-Financial Reporting Harmonization in Italian Context, Sustainability 2020, Vol. 12, 92.

7. Carini, C., Rocca, L., Veneziani, M., Teodori, C. (2018), Ex-Ante Impact Assessment of Sustainability Information - The Directive 2014/95, Sustainability, Vol. 10, 560.

8. Dumay, J., La Torre, M., Farneti, F. (2019), Developing Trust Through Stewardship: Implications for Intellectual Capital, Integrated Reporting, and the EU Directive 2014/95/EU, Journal of Intellectual Capital, Vol. 20, No. 1, pp. 11-39.

9. Dumitru, M., Dyduch, J., Gușe, R.-G., Krasodomska, J. (2017), Corporate Reporting Practices in Poland and Romania - An Ex-Ante Study to the New Non-Financial Reporting European Directive, Accounting in Europe, Vol. 14, No. 3, pp. 279-304.

10. Dyduch, J., Krasodomska, J. (2017), Determinants of Corporate Social Responsibility Disclosure: An Empirical Study of Polish Listed Companies, Sustainability, Vol. 9, 1934.

11. Fărcaş, T.V. (2020), Study about the Implementation of the Directive 95/2014 in Romania - Legislative Perspective and the Actual Application, Audit financiar, nr. 2, pp. 339-351.

12. Grewal, J., Riedl, E.J., Serafeim, G. (2018), Market Reaction to Mandatory Nonfinancial Disclosure, Management Science, Vol. 65, No. 7, pp. 1-24.

13. Jamali, D., Neville, B. (2011), Convergence Versus Divergence of CSR in Developing Countries: An Embedded Multi-Layered Institutional Lens, Journal of Business Ethics, Vol. 102, pp. 599-621.

14. Kamiński, R. (2018), Non-Financial Reporting in the Light of International Regulations and EU Directives, Adam Mickiewicz University Law Review, No. 8, pp. 167-184.

15. Kinderman, D.P. (2015), The Struggle over the EU Non-Financial Disclosure Directive, WSI-Mitteilungen, No. 8, pp. 613-621.

16. Klaus, S., Aykut, B., Jan, K. (2016), Implication of the New EU Directive for Disclosing Non-Financial Information on Sustainability, Environment and Social Aspects, Vision 2020: Innovation Management, Development Sustainability, and Competitive Economic Growth, Vol. I-VII, pp. 998-1007.

17. Krištofík, P., Lament, M., Musa, H. (2016), The Reporting of Non-Financial Information and the Rationale for Its Standardisation, E a M: Ekonomika a Management, Vol. 19, No. 2, pp. 157-175.

18. La Torre, M., Sabelfeld, S., Blomkvist, M., Tarquinio, L., Dumay, J. (2018), Harmonising Non-Financial Reporting Regulation in Europe. Practical Forces and Projections for Future Research, Meditari Accountancy Research, Vol. 26, No. 4, pp. 598-621.

19. Malecki, C. (2018), French Implementation of the EU CSR Directive: Sustainable Corporate Governance Has Begun, Law and Financial Markets Review, Vol. 12, No. 2, pp. 86-92.

20. Manes-Rossi, F., Tiron-Tudor, A., Nicolò, G., Zanellato, G. (2018), Ensuring More Sustainable Reporting in Europe Using Non-Financial Disclosure - De Facto and De Jure Evidence, Sustainability, Vol. 10, No. 4, 1162. 
21. Marinescu, A-O. (2020), Adoption of Non-Financial Reporting Practice of the Companies Listed on Bucharest Stock Exchange, Audit financiar, vol. 18, nr. 1(157), pp. 209-218.

22. Matuszak, Ł., Rózańska, E. (2017), CSR Disclosure in Polish-Listed Companies in the Light of Directive 2014/95/EU Requirements: Empirical Evidence, Sustainability, Vol. 9, 2304.

23. Monciardini, D., Dumay, J., Biondi, L. (2017), Integrated Reporting and EU Law. Competing, Converging or Complementary Regulatory Frameworks?, University of Oslo Faculty of Law Research Paper No. 2017-23.

24. Nobes, Ch. (2006), The Survival of International Differences under IFRS: Towards a Research Agenda, Accounting and Business Research, Vol. 36, No. 3, pp. 233-245.

25. Peršić, M., Janković, S., Krivačić, D. (2017), Sustainability Accounting: Upgrading Corporate Social Responsibility, CSR, Sustainability, Ethics \& Governance, pp. 285-303.

26. Popescu, C.R., Banța, V.C. (2019), Performance Evaluation of the Implementation of the 2013/34/EU Directive in Romania on the Basis of Corporate Social Responsibility Reports, Sustainability, Vol. 11, 2531, available online at https://www.mdpi.com/2071-1050/11/9/2531.

27. Saenger, I. (2017), Disclosure and Auditing of Corporate Social Responsibility Standards: The Impact of Directive 2014/95/EU on the German Companies Act and the German Corporate Governance Code, in Corporate Governance Codes for the 21st Century: International Perspectives and Critical Analyses, pp. 261-273.

28. Tiron-Tudor, A., Nistor, C.S., Ştefănescu, C.A., Zanellato, G. (2019), Encompassing Non-Financial Reporting in a Coercive Framework for Enhancing Social Responsibility: Romanian Listed Companies Case, Amfiteatrul Economic, vol. 21, nr. 52, pp. 590-606.

29. Venturelli, A., Caputo, F., Cosma, S., Leopizzi, R., Pizzi, S. (2017), Directive 2014/95/EU: Are Italian Companies Already Compliant?, Sustainability, Vol. 9, 1385.

30. CNVM (2006), Regulation No. 1/2006 on issuers of and operations with securities.

31. Comisia Europeană (2017), Comunicare a Comisiei. Ghid privind raportarea informațiilor nefinanciare (metodologia de raportare a informațiilor nefinanciare), Bruxelles, available online at https://ec.europa.eu/ transparency/regdoc/rep/3/2017/RO/C-2017-4234-F1-RO-MAIN-PART-1.PDF.

32. European Union (2014), Directive 2014/95/EU of the European Parliament and of the Council of 22 October 2014 amending Directive 2013/34/EU as regards disclosure of non-financial and diversity information by certain large undertakings and groups, Official Journal No. L 330/15.11.2014.

33. Global Reporting Initiative (GRI) (2017), G4 Sustainability Reporting Guidelines, available online at https:// www2.globalreporting.org/standards/g4/Pages/default.aspx.

34. Order of the Minister of Public Finance No. 1286/2012 for the approval of the Accounting regulations according to the International Financial Reporting Standards, applicable to the companies whose securities are traded on a regulated market, Official Journal No. 687/04.10.2012, with subsequent amendments and supplements.

35. Order of the Minister of Public Finance No. 1802/2014 for the approval of the Accounting regulations regarding the individual annual financial statements and consolidated annual financial statements, Official Journal No. 963/30.12.2014, with subsequent amendments and supplements.

36. Order of the Minister of Public Finance No. 150/2015 amending and supplementing the Accounting regulations according to the International Financial Reporting Standards, applicable to the companies whose securities are traded on a regulated market, approve by the Order of the Minister of Public Finance No. 1286/2012, Official Journal No. 136/23.02.2015.

37. Order of the Minister of Public Finance No. 1938/2016 amending and supplementing certain accounting regulations, Official Journal No. 680/02.09.2016.

38. Order of the Minister of Public Finance No. 3456/2018 amending and supplementing certain accounting regulations, Official Journal No. 942/07.11.2018. 